\title{
Enlargement by Stealth?
}

\section{Bulgaria's EUNegotiations between the Political and the Technical}

\author{
Antoaneta L. Dimitrova \\ Leiden University, The Hague, the Nederlands \\ a.l.dimitrova@fgga.leidenuniv.nl
}

\begin{abstract}
This article argues that the EU's enlargement negotiations with Eastern European applicants have become possible to a large extent by the introduction of objective assessment by the Commission, which allowed integration to proceed despite the threat of deadlock. The process of negotiations and preparation, however, should be better seen as a constant switching between the technical parts of the acquis and their (potential) political consequences. These arguments are developed in an analysis of Bulgaria's path to accession. The analysis shows that in the domestic arena, the same tensions between the seemingly technical character of the negotiations and their political implications and consequences can be observed. The article will argue that while the emphasis on objective criteria and technical issues obscured the potential political consequences and effects on various sectors of the economy and society, stalled reforms in public administration or the judiciary belonged to the realm of its unintended consequences. Rule of law did not reform significantly despite the introduction of a special tool of political conditionality, the EU's Cooperation and Verification Mechanism (CVM). The politicization of issues changed over time, with some measures affecting political cleavages more than a decade after Bulgaria's accession.
\end{abstract}

\section{Keywords}

Bulgaria - EU Enlargement - accession negotiations - politicization 
There are corrigenda for this article. Please refer to the corrigenda sheet here: https://www.doi.org/10.30965/18763332-04402014

\section{Introduction: the Two Faces of EU Enlargement}

The politicization of European integration, a process whereby a number of policies and sectors involved in integration become salient in domestic debates and the subject of political contestation in the member states, has been gaining pace since the late 1990s. In contrast to the European Community's ${ }^{1}$ previous decades, when citizens appeared to tacitly approve steps towards further integration, from 2000 onwards the 'permissive consensus' for European integration has been replaced by a 'constraining dissensus' as shown by analyses of political party positions and public opinion (Hooghe and Marks 2009; Kriesi et al 2013).

While analyses of politicization have focused on political constraints to the 'deepening' of integration, that is, further integration of policies among EU member states, with regard to 'broadening' of the EU's geographical scope enlargement - public opinion constraints were present already at the time of Spanish and Portuguese applications. Enlargement has always presented a political challenge, from the first attempts of the United Kingdom to join the original six (Preston 1998).

Enlargement involving countries which were seen to be less developed economically or politically unstable has been especially politically sensitive. Thus, the proposed enlargement of the EU to the East was controversial from the start. Even as it became possible - by virtue of historical transformations rather than the EU's desire to enlarge - the accession of the post-communist states was expected to put a strain on the EU's institutions, policies and budget.

Commissioned to get a grasp of the challenges, a 'three wise men' report warned of the institutional risks of absorbing so many candidate states (Weizacker at al 1999). Yet the political leaders of the Union, especially the leaders of Germany and France, saw enlargement as a historical obligation and a historical responsibility for Eastern Europe (Interview 4a; Baun, 2000). Other member states, such as the Netherlands, were notably skeptical. Some viewed the association agreements concluded in the mid-1990s as the final step in establishing relations with CEE states (Avery and Cameron 1998:17). Trade based

1 The term European Union (EU) is used throughout except when referring specifically to the period before the treaty of Maastricht establishing the EU.

2 For the list of interviews, see the appendix. 
on the agreements was more advantageous for the EU, yet the (rhetorical) commitments of political leaders such as German Chancellor Kohl and French President Mitterand to the unification of Europe helped to overcome reluctance to enlarge (Schimmelfennig 2001). Geopolitical considerations at the end of the Cold War and the desire to stabilise Europe played their role as well.

Evoking the historical obligation of re-uniting Europe was the political justification for initiating the first steps of enlarging to the East. In parallel, seeking to overcome the numerous obstacles facing the EU and the candidates, the European Commission and pro-enlargement member states framed enlargement as the complete opposite of political: an objective process based on measurable criteria (Friis 1998; Landaburu 2007). The Commission's objectivity in assessing candidates' readiness to proceed with negotiations or, ultimately, accession, was seen by reluctant member states as a safeguard against accession of 'unprepared' member states. An objective assessment implies assessment according to strict and clearly defined criteria, scoring candidates according to their progress in adjusting to EU conditions and criteria. The European Council formulated such criteria in 1993 in Copenhagen, defining democracy, market economy and compliance with the acquis as the cornerstones of the Union (European Council 1993).

The Commission's enlargement approach built on the Copenhagen criteria, increasingly emphasising conditionality, which became the key tool of enlargement policy. Conditionality was broadened to include political aspects, such as democracy and minority protection, that had never been addressed before (Grabbe, 2001, 2006; Pridham 2007, 2008; Sasse 2008).

Linked to the objectivity frame and conditionality, a technocratic approach emerged as a way to cope with the sheer magnitude of assessing the candidates. In 1994, the Commission prepared the White Paper on the Internal Market, which was used in the initial screening of the readiness of applicants. The screening exercise already defined a certain technocratic approach, yet the political will and commitment of governments to introducing missing institutions and policies were also considered (Interview 3). Thus, the high politics of grand bargains between the member states on enlargement morphed into Commission-led low politics of screenings of the candidates' existing institutions and policies, formulating conditions and preparing positions and producing regular progress reports.

This article will argue that the switches between objective-technical and political have facilitated enlargement to the East by avoiding deadlock. Resorting to 'objective' assessments through a technocratic approach, however, has also helped political leaders prevent difficult debates. This was helpful for EU member states' governments, on the one hand, to set aside the diversity between candidates and overcome lack of support (Friis 1998). On the other hand, the 
technical approach was also helpful for the governments of candidate states to avoid the politicisation of difficult issues.

An insufficiently explored question is whether the seemingly objective and technical aspects of enlargement have had political effects, in the sense of affecting political cleavages, creating new winners or losers or reinforcing the position of specific domestic interests and stakeholders. A related question is whether the political aspects of enlargement have actually become politicised: that is, whether the rhetoric used during the negotiations has filtered to domestic debates and party cleavages or has brought important arguments in the sphere of public opinion. Last but not least, does the tension between political and technical aspects of enlargement help us understand better the yet unresolved issue of whether EU accession has limited, facilitated or left unaffected trends of state capture in post-communist states?

This article will attempt to shed some light on these questions by examining important areas of the enlargement negotiations and subsequent reform. Focusing on Bulgaria, the article will analyse processes of enlargement unfolding at different levels and in different arenas, between the technical aspects of adapting standards, procedures and policies and the political aspects of bargaining and contestation in the domestic arena. Drawing on interviews with European and Bulgarian officials and a broad range of sources including Bulgarian negotiating positions, the article will explore Bulgaria's negotiations through the prism of the duality between the political and technical aspects of enlargement.

The choice of Bulgaria as a case has a dual motivation. On the one hand, Bulgaria's accession negotiations and the path to enlargement have been relatively underresearched. ${ }^{3}$ On the other, the country's accession is often taken as an example of a political act violating the objectivity of the accession process. This makes it particularly interesting to examine how the political and technical aspects of the accession process played out.

The article aims to show that objective-technical and political aspects of enlargement prevailed in different arenas and at different moments of the process, at the EU level and in Bulgaria. It will argue that while the emphasis on objective criteria and technical issues obscured the potential political consequences and effects on various sectors of the economy and society, some of these were visible to governments and their negotiators. These were the areas such as land ownership - where derogations and transitional periods were requested during the negotiations. Other effects, in particular (complete or

3 For instance, the path of the 2004 entrants has been documented in the volume by Vassiliou (2007), which includes chapters by negotiators and key officials. Unfortunately, Bulgaria and Romania are not part of this volume. 
incomplete) reforms in public administration or the judiciary, belonged to the realm of unintended consequences. Yet other areas, such as rule of law, did not benefit from political reform and subsequent contestation despite the introduction of a special tool of political conditionality: the EU's Cooperation and Verification Mechanism (CVM).

The article proceeds as follows: in the next section, the key organising concepts of 'political' and 'technical' will be discussed. Then, the following section will describe the emergence of these dual aspects of the EU's Eastern enlargement, with an emphasis on the Copenhagen criteria. The following sections will highlight the political and technical elements in Bulgaria's accession negotiations in turn. Starting from the general (political) context of Bulgaria's accession and focusing on selected areas - 'technical' (the environment), 'technical/political'(land ownership, closure of nuclear power station reactors) and 'political' (judiciary, CVM) - this article will analyse how these issues were handled and whether difficult issues remained under the radar, or, conversely, became politicised. The penultimate section will highlight the limitations of the CVM as an instrument of political conditionality and will be followed by conclusions.

The above-mentioned emergence of the Commission's objectivity frame (Friis 1998), combined with the EU's technical assistance and the genuinely technical character of large portions of the EU acquis, have shaped the perception of enlargement negotiations as technical. However, this has not necessarily been the case. As shown by Héritier, making changes below the political horizon, 'by subterfuge' (1999:12), is a mechanism that helps to further integration when political interests and diverse preferences cause deadlock.

The causes for switching arenas and frames have been investigated by scholars of the Eastern enlargement as well (Avery and Cameron 1998; Friis 1999; Maniokas 2004; Schimmelfennig 2001). A number of analyses highlighted the difficulties and challenges presented by Eastern enlargement as a 'high politics' project. Some identified the crucial role of rhetorical action in achieving agreement to enlarge (Friis, 1999; Schimmelfennig 2001; Henderson 1999). Others highlighted changes in the methodology of enlargement emphasising conditionality and empowering the European Commission (Maniokas 2004). Yet others analysed the effects of asymmetry in the negotiations and other key characteristics such as the emphasis on the executive, the increased pace of legislative change and the limited public debate (Grabbe 2004, 2006; Dimitrova and Kortenska 2017). Thus, it can be argued that the emphasis on the technical 
side of the very political process of Eastern enlargement has allowed governments of reluctant member states to keep enlargement-related policies out of the public eye (Dimitrova and Kortenska 2017).

The analysis of Bulgaria's accession will examine EU acquis areas and issues in the negotiations situated on different places in the political-technical spectrum. For the purpose of this analysis, technical and political aspects will be defined as follows: when issues are labelled as political, they are assessed as relevant to the system of democratic institutions or have a political effect in the national or EU arena. Political issues are also (potentially) capable of mobilising constituencies and interests and reflect existing or emerging cleavages in society. Technical, then, refers to issues which are policy-specific, often complex, and require specialised knowledge. At the same time, as the discussion above shows, 'technical' has often been intentionally used to bring difficult issues into an uncontroversial arena for decision-making, away from the public eye.

There is an important further distinction between political and politicised issues. Not all political issues become politicised or contested. When issues become politicised, they come into the sphere of public attention, become subject of political debate and/or the subject of broader societal contestation.

No other episode of enlargement history shows so clearly the switching between political and technical arenas as the emergence of the EU's Copenhagen criteria and subsequent development of conditionality.

The Copenhagen Criteria: between Objectivity and Politics

Following the crucial decision-making at the Luxembourg European Council, the framing of enlargement negotiations as an objective process of assessing the readiness of candidates was taken on board by EU politicians and officials alike. It was so successful that in subsequent years most participants came to describe the negotiations as an objective and 'technical' process of adjustment to the EU. Even the reform or creation of key institutions such as high councils of the judiciary, anti-discrimination commissions or constitutional courts came to be approached as technical tasks.

The prevalence of the objective frame for the negotiations was strengthened by the trend of providing 'technical' assistance, a long-standing feature of support via international organisations. Next to the EU, the International Monetary Fund (IMF), the European Bank of Reconstruction and Development (EBRD) and many others all provided so called-technical assistance, mostly in the form of projects developing specific know-how, expertise or 
systems. The implication of the choice for technical assistance is that countries in transition lack capacity, expertise and knowledge rather than political will. Reaching commonly accepted standards is, then, a matter of capacity rather than politics.

Until the Eastern enlargement, negotiations have focused on issues which could literally be described as technical: standards and product regulations which were part of the acquis (Preston 1998). Given that the post-communist countries were still in transition, however, the EU needed to formulate truly political criteria and conditions. Thus, a set of criteria of an undeniably political nature was formulated by the European Council in 1993 in Copenhagen. They were defined in response to the applications from the post-communist states of Central and Eastern Europe and their wish not only to join, but to become market economies and democracies. Since then, the EU's Copenhagen criteria are used for the assessment of any candidate that officially applies for membership.

Examining the Copenhagen criteria, it is clear that there are aspects which are hard to assess objectively. The first, so-called political criterion, requiring a candidate to achieve stability of democratic institutions, rule of law and respect for human and minority rights and democratic principles, is both crucially important for starting negotiations and very hard to define. The EU had not been involved in democracy assessment ever before, having outsourced that task to the Council of Europe. Not only did the EU lack existing requirements for what the political criterion would entail in terms of institutional and political development, but the formulation of such requirements had very few common practices and institutions among existing member states to draw on (Interview 4c).

Nevertheless, in the mid-199os the Commission developed an assessment approach for aspects of democratic development based on the input of experts from the candidate states (Dimitrova 1996). These inputs built on in-depth knowledge of the transformations of the post-communist states at the time but were also aspirational and aimed to establish norms which were far from commonly accepted.

The second Copenhagen criterion, market economy, appears at first glance more amenable to objective assessment, economics being a science of indicators and numbers, yet Commission officials had difficulties in defining the boundary beyond which candidate states would become market economies, capable of withstanding competitive pressures within the Union. The transition from planned economy and the economic crisis the candidates underwent made the assessment of trends and progress more difficult, even if the 
availability of classical measures such as GDP, inflation and FDI made this a somewhat more objective exercise.

The one area in which it was possible to assess progress objectively, since the EU had quite a bit of experience from previous enlargements, was the third criterion of Copenhagen, adoption of the acquis. The adoption of EU legislation was not easy, since it included, among others, the directives and regulations of the internal market. Yet it was possible for the $\mathrm{EU}$ and candidate states to focus on the 'technical' aspects of the acquis that could be adopted in ways so uncontroversial as to be near invisible to the public. Directives could be transposed into laws relatively fast, which led, not only in Bulgaria but in other candidate states as well, to a high pace of legislative production and numerous subsequent amendments.

Despite the inherent lack of precision in the functioning of democratic institutions or the existence of a market economy, the subject of the first two Copenhagen criteria, the EU managed to develop a method which assessed progress based on regular yearly reports. This reinforced the idea of objectivity as the main feature of the process and also - coincidentally - the Commission's role as gate keeper (Maniokas 2004).

The transition from political to technical - and back - on which this article focuses is well visible in the comparison between the high, value-led politics captured in the Copenhagen criteria and the day-to-day politics of assessing progress and negotiating that favoured the technical. Progress in transposing the EU's acquis was the criterion which was the easiest to follow and assess objectively. The acquis and its various aspects were the core of the negotiations: according to Avery and Cameron, participating in enlargement as Commission officials, negotiations were about how the candidates would take on board the rules of the club, the EU's acquis. They emphasized that 'only technical adjustments and temporary derogations are possible' (1998:32-33). Therefore, on the candidates' side, the negotiation positions, by virtue of the character of the process followed the EU acquis closely. The negotiation positions also aimed to provide derogations and some rare exemptions where the costs of the adaptation appeared too high. By the time accession negotiations were completed enlargement inevitably returned to the realm of high politics, with the necessity to present and ratify the treaties of accession.

The following sections examine in some detail a number of aspects of Bulgaria's negotiations and key issues arising in the pre-accession that can be shown to have exhibited both political and technical features at different moments. 


\section{Bulgaria' Accession Negotiations and Reforms}

\subsection{From the Political to the Technical}

Bulgaria's path to EU membership was rocky and difficult. To this day, there are commentators and politicians that still consider Bulgaria's membership premature. Historically, it did not help that Western leaders' determination to repair historical injustice and re-unite Europe was less strong with respect to Bulgaria and Romania than, for example, with regard to Hungary or Poland (Interview 4b).

Bulgarian negotiators got a first sense of the difficulty of the path to the EU already during the negotiations for an association agreement with the European Union. In contrast to Central European post-communist states, Bulgaria's association agreement treaty contained a specific clause, the so-called Bulgarian 'suspension' clause (Dimitrova and Dragneva 2002:142). It made the operation of the treaty conditional on respect for human rights and democratic principles and made it possible to suspend it in case of violations. In fact, the Bulgarian clause was an early step by the EU in the use of political conditionality, which was later applied to other countries, including the Czech Republic and Slovakia when they re-negotiated their agreement after the split of Czechoslovakia.

Bulgaria was excluded from the first group of countries invited to start negotiations. The most important reason for this was the complete absence, at the time, of meaningful economic restructuring and reforms and the lack of political will - until the Kostov government of 1997 - for initiating the transition to a market economy (Interview 4b). Despite the common perception that delay was due to problems with rule of law or corruption, these issues played less of a role in the EU's initial decision to postpone the start of negotiations with Bulgaria (Interview 3).

The green light given to the Bulgarian negotiations by the European Council in 1999 in Helsinki was seen to have geopolitical reasons. The geopolitical impulse was provided by the active support by both Bulgaria and Romania for NATO actions to protect Albanians in Kosovo in the spring of 1999. At the same time, the Bulgarian government actively lobbied for starting negotiations. Like the leaders from Central Europe who strategically argued that their countries should 'return to Europe' (Schimmelfennig 2001), Bulgarian Prime Minister Kostov engaged in rhetorical action through high-profile interviews and statements emphasizing the benefit of having Bulgaria as a stable ally in the turbulent Balkans (Tosheva, 1999). The invitation to start negotiations, when it came, was, therefore, viewed as a political decision weakening the objective character of the Commission's approach (Interview 4 b). 
In response, Bulgaria's government proceeded very rapidly with reforms. The political will to initiate a strong programme for transitioning to a market economy was recognised by the European Commission, as well as the IMF and the World Bank. The Commission opinion of 1997 and the Agenda 2000 also reflected the new start (Interview 3).

The level of expertise mobilised between 1997 and 2002 - the crucial years of negotiation and preparation - were unprecedented for Bulgaria's transition period. The Union of Democratic Forces government, led by Ivan Kostov, initiated broad reforms involving wide-scale privatisation and re-structuring including the creation of a currency board pegging Bulgaria's lev to the German mark (later the euro). As a result, inflation went down from $210 \%$ in 1996 to only $5.7 \%$ in 1998 (Hristova and Angelov 2004, based on National Statistical institute data). Wide-ranging economic restructuring helped Bulgaria to recover economically and to become a credible candidate state. However, the transition to market economy that started after the crisis of 1996 also had its costs in terms of affecting industries that, even if outdated, were major employers.

The European Union supported social policy and similar measures such as severance payments through direct budget support. This support was ad hoc rather than programmatic and was linked to issues that differed by country and came up during the negotiations of specific chapters. It helped cushion the impact of re-structuring and softened the potential political effects of reform (cf Bruszt and Langbein 2017).

Somewhat more reluctantly, the Bulgarian government also initiated reforms in key state institutions such as the administration and judiciary (Dimitrova 2002; Ganev 1997). This was a response to specific EU conditionality targeting administrative neutrality and judicial reform, but also a reflection of the fact that political consensus for accession and for the reforms deemed necessary to achieve it was high among all political parties (Velichkov 2004). As the legitimacy of EU accession as a foreign policy choice was quite high and furthermore, civil servants stood to benefit from legislation defining their position, administrative reform, while far-reaching, did not become truly politicised.

Under the radar, however, processes of state capture were hindered by legislation limiting political interference in the administration or the establishment of regulatory bodies. Pushback from rent-seeking elites benefitting from state capture slowed down reforms in key areas such as the rule of law and the struggle against organised crime. The EU, receiving critical signals from civil society in Bulgaria and concerned member states, became increasingly aware of reform stagnation in key areas, yet it did not have the tools or even - initiallythe ambition to deal with state capture. Only as accession neared, and pressure 
from concerned member states increased, did the Commission come up with additional monitoring through the Cooperation and Verification Mechanism (CVM).

\subsection{The Turn to the Technical}

As negotiations proceeded, the balance between technical and political aspects tilted towards the technical. As with all the candidates, the EU approach to Bulgaria in the early 2000 s emphasised institution-building, mostly through legislation. Important framework legislation and strategies were required and adopted, such as, among others, the strategy for the development of public administration (1998). Even the constitutional amendment taking the prosecution out of the system and control of the Ministry of Justice was accomplished with relatively little opposition, at least formally.

Public administration reform had been a contentious issue with political dimensions in the last phase of the pre-negotiations period. The UDF government and the prime minister himself were not keen to provide job protection for civil servants. In all candidate states, political elites did not want to relinquish their ability to hire and fire civil servants on a large scale after an electoral win (Meyer-Sahling 2004). The European Commission reminded the Kostov government of the commitment to administrative reform in a dedicated letter, just before the decision on Bulgaria's negotiations. The relevant laws were adopted soon afterwards (Dimitrova 2002).

Despite the need for several subsequent amendments to anchor meritbased recruitment in the administration, the first wave of legislation passed in 1999 drastically limited the turnover of administrative staff, which in turn facilitated the continuity of negotiations and the formulation of positions under the various chapters. Post accession, however, processes of politicisation of the administration became more prominent, especially from 2010 onwards (Zankina 2017).

Administrative capacity-building was led by the blueprint developed by SIGMA (OECD). Planning capacity was weak in the aftermath of the collapse of the planned economy, so the adoption of a strategy was seen as a good first step. The EU's requirements for adopting strategies, however, sometimes represented a back door for various member state interests in the negotiations, resulting , according to one expert, in 'a sea of strategies': at one point in the early 200os, Bulgaria's government was called upon produce 116 strategic documents (Interview 2). However, it soon became clear that the adoption of a strategy by the government through the parliament (National Assembly) postponed addressing specific policy problems. By 2006, haphazard 
implementation led the Commission to abandon the demand for strategies and to seek real policy change (Interview 3 ).

A typical feature of negotiation politics driven by the characteristics of the process was that negotiation-driven reforms proceeded at a pace that did not allow much input from relevant stakeholders or societal discussion, even though the European Commission formally encouraged their involvement. The large body of legislation passed and amended in the pre-accession period, despite its potential political impact, remained de-politicised even if not always technical. Initially only few negotiation team members and experts, mostly in the European integration units of the Council of Ministers and the ministries, understood the desired impact of the amendments on the law on the judiciary, the functioning of administrative courts or the new Penal Code.

In fact, the numerous, seemingly small and technical, changes mostly led to improvements in governance. Between 2001 and 2003, competition-based hiring was introduced with an amendment to the law on the civil service. The practice of replacing large numbers of civil servants with every change of government was curtailed (Nikolova 1999; Verheijen and Kotchegura 1999).

Competitive hiring became compulsory in 2006, even if many exceptions remained a possibility (Interview 3). Positions were advertised in the State Gazette and tests and interviews for candidate civil servants were developed as further steps strengthening merit-based hiring. A new system of performance evaluation for civil servants was defined with a ministerial decree, gradually linked to the system of remuneration. Between 2003 and 2006, some elements of career mobility were added, rotating civil servants between ministries to create better coordination and a generalised base of civil servants.

Most importantly, political leaders appeared to accept and understand the importance of public administration as a source of neutral policy-making expertise. Reforms gradually evolved from piecemeal adoption of EU-driven legislation towards the development of policies (Interview 2).

\subsection{Between the Political and the Technical}

An interesting set of policies to examine are the ones which appeared highly technical, but became politically salient after accession. Such policy measures and parts of the acquis could be found in environmental policy, transport and social policy. The following paragraphs will examine some of the key issues in the negotiations and transitional periods and briefly highlight the developments some years later to illustrate the fluid nature of the issues.

Several areas of the acquis are by nature technical, in the sense that they involve and require highly specialised knowledge and expertise to transpose 
and implement. One such area is the environmental acquis, considered by all candidate states to be costly and challenging to take on board.

In general, despite the economist costs, adjustment to the EU's environmental standards during pre-accession has contributed to a significant improvement in environmental conditions. Environmental compliance as a whole improved (Andonova and Tuta 2014). As part of a broad development across the CEE region (Andonova 2004), Bulgaria reduced its industrial emissions more than threefold, from record high levels for the region in 2005 to values comparable to other CEEs in $2015 .{ }^{4}$ Laws on biodiversity and fishing were adopted in 2001. Institutional authorities responsible for implementation and enforcement were designated: the National Nature Protection Service Directorate, 15 regional inspectorates and 3 directorates of national parks with a staff of 250 in total. In addition, requirements for access to information were introduced, as provided by Directive 90/313/EC on access to information on the environment, which was transposed into Bulgarian legislation with the 2001 environmental protection law. A regulation on environmental impact assessment was adopted in 2002.

At the same time, EU acquis regarding air and water quality and waste management were areas with which all candidates found it difficult and costly to comply. For Bulgaria, an assessment was made in 1999 of the investments needed to comply with the environmental acquis, resulting in a figure of about 9 billion euro ( $60 \%$ private / $40 \%$ public investments). In hindsight, even that estimate may have been too modest (Interview 3).

A number of transition periods were requested. One concerned the transposition of Directive 99/32/EC on maximum admissible sulphur content in gas oil (three years and eight for some provisions). Regarding the EU's requirements for disposal of liquid waste and biodegradable waste, Bulgaria requested a derogation or a transitional period until 2020. A transitional period of two years was requested on biodegradable municipal waste, while five years were requested for the attainment of minimum recovery of packaging waste requirements. On the latter, the Bulgarian side cited the lack of suitable incineration installations in its position. Regarding Directive 94/63/EC on voc emissions from storage, loading and unloading of the transport of petrol, a transitional period of three years was requested for the technical requirements of compliance of existing installations.

The adopted environmental acquis, together with other international law such as the Aarhus convention embedded Bulgaria's environmental legislation into a larger network of national and international rules. The new rules would

4 Data from the European Environmental Agency can be found here: https://www.eea.europa .eu/data-and-maps/figures/country-comparison-implied-emission-factors. 
make a considerable impact on spatial planning, building permits and (illegal) construction decades later. They provided for key improvements in Bulgaria's nature protection legislation and strengthened existing protection schemes such as national parks.

In general, however, there was a lack of knowledge and expertise regarding the content and impact of the adopted measures, which was exacerbated by the lack of coordination between the negotiating teams dealing with energy policy and the environment (Interview 3). By necessity, when the necessary characteristics of the protected biodiversity and habitat zones under Natura 2000 had to be determined, this took place in scientific seminars with experts rather than politicians. Thus, defining of the scope and size of the Natura 2000 territories went almost unnoticed, in contrast to many other areas of the acquis.

The interesting twist in the case of Bulgaria's chapter 22 negotiations on the environment is that the requested transitional periods were not, in fact, related to areas which are currently problematic such as air quality or Natura 2000. Despite passing relatively unnoticed through the negotiations, commitments for nature protection linked to the Natura 2000 network became highly political some years after accession. They came to be in opposition to development ambitions - as they did in other countries in the Eastern enlargement such as Poland ${ }^{5}$ and Romania. In 2012, proposed amendments of the forestry law caused large-scale protests. Even as the draft law was not directly part of the environmental acquis, its contestation was facilitated by the presence of active domestic environmental networks that had been involved with the environmental acquis adoption (Dimitrova and Buzogany 2014).

Not only the size and protection in the Natura 2000 network, but other issues such as air quality have proven to be the subject of political contestation in recent years. While legislation transposing EU acquis on clean air was adopted already in 1999-2000 and relatively 'simple' measures such as the creation of the national environmental information system with stations measuring air quality were adopted fast, air quality did not improve sufficiently.

In recent years, the development of citizen science frameworks and measurement units has reinvigorated the debate and shown that Bulgaria, alongside with Poland, has recorded some of the worst pollution values for large cities in Europe. ${ }^{6}$ Air quality has remained a problem due the complexity of

5 In Poland's case, the conflict between Natura 2000 requirements protecting the Rospuda valley and the development and infrastructure ambitions of the government started already in Poland's first years as an EU member (Szulecka and Szulecki, 2012).

6 The European Air Quality index, providing real-time measurements, can be found here: https://airindex.eea.europa.eu/. 
the measures needed and the low level of resources and attention by policy makers. In 2011, Bulgaria had most frequently exceeded daily limit values for concentration of particulate matter (PM) in the EU, followed by Poland, Slovakia and Hungary. Other aspects of air quality such as $\mathrm{O}_{3}$ concentration and nitrogen dioxide scored worse in Central and Southern Europe (Guerreiro et al 2014:379-381).

Another example from negotiating chapter 13, Social Policy, also touches upon public health with serious, if unexplored, consequences. A nine-year transitional period was requested by Bulgaria regarding the requirements related to the maximum tar yield from cigarettes under Directive 90/239/EEC. This was officially motivated by the need to implement the necessary changes in processing and production of tobacco products, but remained a dubious choice (Interview 3 ). This request was likely affected by private interests linked to Bulgartabak, a large company engaged in tobacco production, a key industry (in terms of employment) at the time. However, neither the negotiations nor subsequent developments in public policy on smoking have led to any meaningful societal debate on role of the tobacco industry in Bulgaria.

As discussed above, transitional periods indicate which areas were seen as most problematic politically or technically, in terms of the measures and steps to be taken for adjustment to EU standards. The absence of political debate around the transitional periods on oil and gas installations and tar in cigarette suggests that these were expected to be problematic in terms of their impact, for example in terms of the economic effects on households of changing outdated vehicles.

There were, however, several issues on which debates arose and even, in one case, provoked a domestic backlash against EU conditions. The sale of land to EU citizens and the closure of nuclear reactors were the most important ones. These issues arose in several candidate states, suggesting a link with the various legacies of communism.

\subsection{Back to Politics}

In the Bulgarian negotiations, the sale of land to non-Bulgarian (EU) citizens was a very sensitive and problematic issue, as it was in Poland and Hungary (Gottfried and Gyorkos 2007: 194-195). Opening the land market for arable land and second residences was embedded in chapters on the free movement of persons and capital. In Bulgaria, it required an amendment of article 22 of the Constitution, prohibiting the acquisition of land by foreigners (Velichkov 2004).

Given the political sensitivity of the issue, Bulgaria requested and received a transitional period which restricted foreigner land acquisition via a moratorium until 2014, arguably allowing large-scale Bulgarian agricultural landowners 
to consolidate. Sale of agricultural land has remained contentious even after this: after the transition period, between 2014 and 2017, EU citizens were allowed to buy arable land only if they had resided in Bulgaria for 5 years. In 2019, a new draft law was introduced finally opening the market for agricultural land.

The closure of reactors 1 to 4 of Bulgaria's Soviet-type nuclear power plant in Kozloduy was the other contentious and politicised issue of the negotiation period, both between Bulgaria and the EU and within Bulgaria's political arena. Antoaneta Primatarova, former deputy foreign minister, and later Ambassador to the EU, analysed the issue as the crisis in Bulgarian accession negotiations. For example, while $80 \%$ of Bulgarians were in favour of EU membership, almost an equal percentage were against the closure of the reactors (Primatarova, 2005).

Bulgaria had committed to the closure in the Nuclear Safety Account Agreement (NSA) signed with the European Bank for Reconstruction and Development in $1993 .{ }^{7}$ While the NSA agreement was seen as binding by the EU, officials and experts from the Bulgarian nuclear sector did not view the issue as resolved. They kept producing technical reports revisiting the safety of reactors 1-4. While technical aspects were difficult to assess for non-specialists, the experts also disputed the character of the NSA agreement for closing the reactors: some asked whether it was in fact a political, rather than a safety measure (Taylor 2001, in Primatarova 2005:98). These arguments were used by political parties - in other words, the issue became highly politicised.

The closure of reactors one to four was set as a condition for the start of negotiations in the Commission's Composite Paper of 1999. A memorandum agreeing on the closure and EU support to mitigate the effects was signed in Sofia in November 1999 (Primatarova 2005:99). This, however, did not close the debate. It continued in the Bulgarian media and in the political arena for at least a decade and remained one of the final conditions which Bulgaria had to satisfy before accession (Grabbe 2003:1022).

Similar to the closure of the Ingalina nuclear power plant in Lithuania (Maniokas 2005), the issue was highlighted by the Bulgarian side as problematic due to the lack of a broad consensus and a variety of technical assessments on the actual danger from the reactors. In addition, regarding the closure of the reactors, the domestic political consensus for accession was fractured.

The Bulgarian Socialist Party, as well as the nationalist Ataka used the issue in their campaigns. Some years later, even the centre-right party $G E R B$ (standing for 'Citizens for European Development of Bulgaria') condemned the closure and claimed they would re-open the reactors. Thus, the closure of

7 A measure influenced by a G-7-initiated safety programme in the aftermath of the catastrophe at Chernobyl. 
the Kozloduy reactors remained in public memory as one of the most contentious issues of the enlargement negotiations that could not be accomplished under the guise of a technical or safety driven process.

Recommendations and criticism targeting reform of the judiciary in Bulgaria were part of the Commission's regular reports in the general section of rule of law and political criteria. The substance of measures and conditions has been difficult to define, as the EU itself has had no acquis or a general approach to strengthening judicial independence (Smilov 2006). Furthermore, as Parau (2014) argued, the EU's general recommendations and conditions related to rule of law focused above all on strengthening the independence of the judiciary.

To illustrate this, the 1998 Commission progress report for Bulgaria explicitly criticizes the delay in the adoption of a law 'to reinforce judicial independence' (European Commission 1998:8). The required law was adopted in October of the same year, as the next regular report noted (European Commission 1999), changing the composition of the Supreme Judicial Council (sJC). The sJC has been established as a permanent administrative body with very wideranging responsibilities to manage the judicial system in Bulgaria. It operates with own budget and 'represents the judicial power and secures its independence, determines its personnel and the work organization of the judicial system, and manages its activities without interfering with the independence of its bodies. ${ }^{8}$ The 2001 Commission report further criticises the Bulgarian executive and parliament for not complying with the Supreme Judicial Council's requested budget but adopting a smaller budget. The report advocates a strong and exclusive role for the legal profession in the composition and functioning of the Supreme Judicial Council. The report criticises the 'unclear split of roles and responsibilities between the SJC and the Ministry of Justice' (European Commission 2001: 18).

According to Parau (2014), the EU's emphasis on strengthening the role of Supreme Judicial Councils in steering the judicial system has created a superindependent judiciary. Rather than strengthening rule of law, it has eroded the ability of legislatures to hold the judiciary accountable. Arguably, the EU's recommendations and requirements did contribute to making the judicial system and especially the Supreme Judicial Council strong and independent, but instead of upholding the rule of law, the sJc became a target to be recruited and influenced by those interested in state capture.

8 Supreme Judicial Council (sJc) official website (English) available at: http://www.justice.bg/ en/start.html. 
Fifteen years after accession, despite being elected from both the judicial and the legislative branch, the SJC is a captured institution that does not defend the rule of law, but specific groups and interests. It has been explicitly and repeatedly criticised by politicians, rank and file judges, legal professionals and NGOS. At the beginning of 2015, the lack of transparency and the controversial appointments of presidents of the Supreme Administrative Court and the Supreme Court of Cassation triggered several open letters by the Union of Judges in Bulgaria and other NGOs, criticising the sJC's exposure to political influence (Fagan et al 2016).

Thus the (incomplete) reform of the judiciary in Bulgaria was an example of an area that was politicised at the end of accession preparations and has attracted a lot of attention since. Rule of law shortcomings were one of the main reasons for the installation of monitoring in Bulgaria after accession, in the form of the 'Cooperation and Verification Mechanism' (CVM).

By contrast, the approval of accession to the EU did not become politicised, despite having obvious and momentous political significance. While the Bulgarian constitution did not require a referendum and parliamentary ratification was sufficient, many candidate states held referenda to secure the approval of the broader public. Neither Bulgaria nor Romania did so, which arguably put less strain on political leaders and created a window of opportunity to finalise the Accession Treaty before parliamentary elections (Interview 3). In this way, Bulgarian governments missed the opportunity to create popular legitimacy and discuss the most momentous decision in Bulgaria's recent history.

\section{The Cooperation and Verification Mechanism (CVM)}

Even if Bulgaria's accession to the EU was not a contested or much debated issue domestically, it certainly became one in the European arena. Following the 2004 enlargement, Bulgaria and Romania were evaluated as lagging behind, while the EU itself experienced a backlash dubbed 'enlargement fatigue' by some. Concerns on the EU side about corruption and organised crime and the weakness of rule of law in both Bulgaria and Romania led to the last-minute setting up of a quasi conditionality mechanism of monitoring, namely the Cooperation and Verification Mechanism (CVM). The CVM mimicked some of the features of the enlargement process such as the yearly monitoring through the issuing of regular reports by the Commission. It was unwelcome for Bulgarian (and Romanian) elites, but it contributed to keeping the issue of corruption in 
public debates and strengthened some anti-corruption actors within government and civil society.

There are several studies examining the success or failure of the CVM in Bulgaria (Dimitrov et al 2014, Gateva 2010; 2013, Toneva-Metodieva 2014; Spendzharova and Vachudova 2012). None of them are very positive about its impact, in contrast to the more positive evaluations of the effects of the CVM in Romania (Trauner, 2009; Sedelmeier and Lacatus 2016).

The paradox of the CVM in Bulgaria is that it remained influential in public debate and yet did not result in substantial changes improving rule of law. There are several reasons for this, chief among them being that post accession, state capture and rent seeking in Bulgaria have not lessened, but become more rampant (Ganev 2013; Rakovita 2011). After 2010, different government coalitions have found a new modus operandi in collaborating with business elites rather than competing to make institutional rules impersonal and universal. The think tank Centre for the Study of Democracy (CSD) noted in 2014 that citizen participation in corruption deals was at its highest levels since 1999 (2014:9). The CSD report suggested that the increasing reluctance of elites to tackle high-level corruption was coupled with increased societal resistance to the phenomenon.

Addressing state capture, patronage and rent seeking is, arguably, the most difficult political task of Bulgarian society, one that has not yet been embarked upon in all seriousness despite some hopeful mobilisation in 2012 and 2013. Yet it is clearly a domestic task and, as with backsliding in other CEE states, can only be really resolved through the mobilisation of society rather than by interventions from outside (Dimitrova 2018; Jenne and Mudde 2012; Vachudova 2013; Mungiu-Pippidi 2020).

Post-accession, the EU did not have much leverage to change the domestic calculations of governing elites. With respect to the EU's role, the CVM shortcomings can be attributed to the formalistic and government-oriented approach and the lack of mechanisms to engage society at large in addressing the well-known problems (Dimitrov et al 2014). In this respect, the CVM suffered from the same shortcomings as the EU's political conditionality as a whole; namely it addressed governments and not societies. Furthermore, the Commission did not have free rein to address openly the democratic weaknesses of old and new member states (Pridham 2007:450).

Thus, the CVM contributed to Bulgaria's (and Romania's) catching up only when there were political gains to be made domestically or when the EU attempted to employ cross-conditionalities (Spendzharova and Vachudova 2012). Ultimately it remains a weak tool, aptly named by Dimitrov et al (2014) an instrument of 'shared political irresponsibility'. 
Reaching for technical solutions and adopting regulation 'by stealth' (Héritier 1999:12) has been a typical way of avoiding political deadlock in the EU. Enlargement negotiations and key decisions were an area where incremental and seemingly technical steps, combined with the Commission's objective evaluation of candidates, appeared to overcome opposition from certain member states. This mechanism, however, appears to have reached its limit in 2019, as the European Council, based on a veto by France, refused to start negotiations with North Macedonia and Albania despite positive opinion by the Commission and 'objective' indications to do so.

Looking back on Eastern enlargement, governments and negotiators struggled to reflect and aggregate domestic interests under conditions of power asymmetry. As transitions from old planned economies to market ones proceeded almost simultaneously with accession negotiations (Dimitrova 2004), governments had to balance between older industries losing employment and the new EU policies driving modernisation. This process was profoundly political, but for the most part not politicised. Debates were limited given the broad consensus on joining the EU (Mirel 2018, Interview 5).

Therefore, conducting reforms consisting of many incremental, 'technical' adjustments was a promising path to changing sectors and institutions crucial for democratic governance. An example was the important process of professionalisation of the administration during the negotiations, whereby the functioning of the administration and the judiciary were reformed, which led to improvements of governance. However, the improvements appeared to be incomplete in some areas and reversible in others.

At the same time, resorting to technical measures did not mean that there were no political costs and societal impact. The cases of the environmental acquis, free movement of capital and labour and land acquisition involved deeply complex issues with considerable consequences. Political conflicts and policy debates around some of these issues have emerged. Other issues, such as the closing of reactors of the Kozloduy nuclear power station, had less economic impact than anticipated even if in that particular instance politicisation was arguably the highest of all negotiation issues.

Despite the fact that negotiating governments could not predict all the effects of the imported rules, they did not engage in consultation on a broad scale to compensate for their own lack of information. Specific choices, such as the long transitional period for adaptation of tar amounts in cigarettes, could have benefitted from debates about their impact on public health. Furthermore, under conditions of little or no debate, laws and policies convenient for 
certain interests could be adopted with the handy excuse of being 'required by Brussels'. The latter, we must note, is a tactic used by most EU member state governments.

Elites in the existing member states also had an interest in keeping certain issues - in fact most of the enlargement negotiations and their progress - out of the public eye due to fears about public opinion and unwillingness to spend political capital on convincing their electorates of the value of Eastern enlargement (Dimitrova and Kortenska 2017).

The lack of time and will for political debates during the pre-accession period has created, after enlargement, opportunities to reverse or weaken the pre-accession reforms, as not many societal actors were engaged with them. Furthermore, it is likely that the well-known emphasis on executives in enlargement negotiations (Grabbe 2006) has contributed to the limited culture of parliamentary debates after accession, not only in Bulgaria, but in most CEE member states. The 'bug' of the enlargement negotiations has become a convenient feature for political leaders and governments that do not have the desire to consult parliaments.

Where societal actors and non-governmental organisations have been engaged, even technical issues have become salient in political debates, such as in the case of air quality measuring stations and the environmental acquis (Dimitrova and Buzogany 2014). It is also possible to enforce EU rules despite the political opposition they now encounter from specific interests.

Reflecting on the reversal of reforms supported by the EU in administrative and judicial institutions, it is important to note that it is not caused by popular dissatisfaction with the functioning of the judiciary or administration. Rather, during the negotiations such reforms remained under the radar of predatory, rent-seeking elites. Members of privileged networks were busy during the preaccession period expropriating funds and building business empires (Ganev 2007). Yet others, perhaps, had hope for new opportunities for self-enrichment via the EU's structural funds, which may have been (partially) realised.

For all involved - be they genuine reformers or the rent-seeking elites that seem to have gotten the upper hand since accession (Ganev 2013; Dimitrova 2018) - there has been no clear sense of how EU rules would intervene in rentseeking schemes. No one could predict whether the EU would be able to control abuse of structural funds (the jury is still out on that). When rent-seeking elites became aware of the constraints that reforms created, they worked to reverse or neutralise them. This is particularly obvious with the developments around the Supreme Judicial Council in Bulgaria and the rule of law in the decade after accession. Yet the EU institutions cannot eternally play the role of institutional doctor when solutions prescribed from outside do not work. 
Domestic constituencies have to take the upper hand in making domestic democratic institutions sustainable and strong.

\section{References}

Andonova, L. B. 2004. Transnational Politics of the Environment: The European Union and Environmental Policy in Central and Eastern Europe. (Cambridge, MA: The MIT Press).

Andonova, L. B and Tuta I. A. 2014. "Transnational networks and paths to EU environmental compliance: Evidence from new member states", Journal of Common Market Studies, 52(4) 775-793.

Avery, G. and Cameron, F. 1990. The Enlargement of the European Union. (Sheffield: Sheffield Academic Press).

Baun, M. 2000. A Wider Europe: The process and politics of European Union enlargement. (Lanham: Rowman and Littlefield).

Bruszt, L., and Langbein, J. 2017. "Varieties of dis-embedded liberalism. EU integration strategies in the Eastern peripheries of Europe", Journal of European Public Policy, 24(2), 297-315.

Bulgarian positions in accession negotiations (initial), available via portal Europe, at: http://old.europe.bg/htmls/page.php?category=225 (accessed 22 November 2019).

Center for the Study of Democracy 2014. "Anticorruption Policies against State Capture", http://www.csd.bg/artShowbg.php?id=17171\#.VIrI1-WOYoo.google_plusone _share (accessed 2 February 2020).

Dimitrov, G., Haralampiev, K., Stoychev, S., and Toneva-Metodieva, L. 2014. The cooperation and verification mechanism: shared political irresponsibility between the European Commission and the Bulgarian governments. (Sofia: St Kliment Ochridski University Press).

Dimitrova, A. L. 1998. "The role of the EU in the process of democratic transition and consolidation in Central and Eastern Europe", in The European Union in a Changing World/'L'Union Européenne dans une monde en transformation: A selection of Conference Papers/Une Selection Des rapports de la Conference, (Brussels: European Commission and ECSA): 315-339.

Dimitrova, A. L. 2002. "Enlargement, Institution Building and the EU's Administrative Capacity Requirement”, West European Politics 25(4): 171-90.

Dimitrova, A. L. 2015. "The Effectiveness and Limitations of Political Integration in Central and Eastern European Member States: Lessons from Bulgaria and Romania," MAXCAP Working paper No. 10 at: http://userpage.fu-berlin.de/kfgeu/maxcap/ system/files/maxcap_wp_10.pdf (Accessed 3 February 2020). 
Dimitrova, A. L. 2018. "The uncertain road to sustainable democracy: elite coalitions, citizen protests and the prospects of democracy in Central and Eastern Europe". East European Politics 34(3): 257-275.

Dimitrova, A.L. and Dragneva, R. 2001. "Bulgaria's road to the European Union: Progress, problems and perspectives", Perspectives on European Politics and Society, 2(1): 79-104.

Dimitrova, A. L. and Buzogany, A. (2014) "Post-Accession Policy Making in Bulgaria and Romania: Can Non-state actors use EU rules to promote better governance?" Journal of Common Market Studies 52(1): 139-156.

Dimitrova, A.L., and Kortenska, E. 2017. "What do citizens want? And why does it matter? Discourses among citizens as opportunities and constraints for EU enlargement", Journal of European Public Policy, 24(2): 259-277.

European Commission (EC) 1998. "Regular Report from the Commission on Bulgaria's progress towards accession”, https://ec.europa.eu/neighbourhood-enlargement/ sites/near/files/archives/pdf/key_documents/1998/bulgaria_en.pdf (accessed 1 February 2020).

European Commission 1999. "Regular Report from the Commission on Bulgaria's progress towards accession”, at: https://www.esiweb.org/pdf/bulgaria_EC-Regular\%20 Report\%2oBulgaria_en_1999.pdf (accessed at 3 February 2020).

European Commission 2001. "Regular Report from the Commission on Bulgaria's progress towards accession”, SEC (2001) 1744 available at: https://ec.europa.eu/ neighbourhood-enlargement/sites/near/files/archives/pdf/key_documents/2001/ bu_en.pdf (accessed 3 February 2020).

European Council (1992/1993) Conclusions of the presidency, European Council in Copenhagen 21-22 June 1993, DN Doc/93/3, available at http://www.europarl.europa .eu/summits/copenhagen/co_en.pdf (accessed 7 June 2019).

European Parliament Briefing no 6, "Bulgaria and the European Union", at: http:// www.europarl.europa.eu/enlargement/briefings/6a3_en.htm (accessed 16 May 2019).

Fagan, A., Sirkar, I., Dimitrova, A., and Kortenska, E. 2015. "Unintended Consequences of EU Conditionality on (Potential) Candidates”, MAXCAP Working Paper No. 14, "Maximizing the integration capacity of the European Union: Lessons of and prospects for enlargement and beyond" (MAXCAP) at: http://userpage.fu-berlin.de/ kfgeu/maxcap/system/files/maxcap_wp14_final_o.pdf.

Friis, L., 1998. "The End of the beginning of Eastern Enlargement - Luxembourg Summit and Agenda-Setting", EIoP 2(7) at http://eiop.or.at/eiop/texte/1998-oo7a.htm (accessed 17 June 2019).

Ganev, V. I. 1997. “Bulgaria's Symphony of Hope”, Journal of Democracy 8(4): 125-139.

Ganev, V. I. 2013. "Post-accession hooliganism: Democratic governance in Bulgaria and Romania after 2007", East European Politics and Societies, 27(1):26-44. 
Gateva, E. 2010. "Post-Accession Conditionality: Support Instrument for Continuous Pressure?", KFG Working Paper Series, No. 18, Kolleg-Forschergruppe (KFG) "The Transformative Power of Europe", (Berlin: Freie Universität Berlin).

Gateva, E. 2013. "Post-accession conditionality - translating benchmarks into political pressure?" East European Politics, 29(4): 420-442.

Gottfried, P. and P. Györkös 2007. "The Accession of Hungary to the EU", in G. Vassiliou (ed.) The Accession Story: The EU from 15 to 25 countries. (Oxford: Oxford University Press): 188-206.

Grabbe, H. 2006. The EU's Transformative Power: Europeanization through Conditionality in Central and Eastern Europe. (Basingstoke and New York: Palgrave MacMillan).

Grabbe, H. 2003. "Europeanization goes east: power and uncertainty in the EU accession process" in Radaelli, C. and K. Featherstone (eds.) The politics of Europeanization. (Oxford: Oxford University press): 303-329.

Grabbe, H. 2001. "How does Europeanization affect CEE governance? Conditionality, diffusion and diversity" Journal of European Public Policy, 8(6): 1013-1031.

Guerreiro, C. B. B., Foltescu, V. and de Leeuw, F. 2014. "Air quality status and trends in Europe", 98: 376-384.

Henderson, K. 1999. Back to Europe: Central and Eastern Europe and the European Union. (London: Routledge).

Héritier, A. 1999. Policy Making and Diversity in Europe: Escaping deadlock. (Cambridge: Cambridge University Press).

Hristova, A. and Anguelov, G. 2004. "Bulgarskiyat bankov sector i finansovata kriza" in Anatomia na prehoda: Stopanskata politika na Bulgaria ot 1989 do 2004 [The Bulgarian Banking sector and the financial crisis in The Anatomy of Transition: Bulgarian Economic Policy from 1998 to 2004]. (Sofia: CIELA), at: http://prehod.omda.bg/ public/knigi/anatomia_na_prehoda.pdf (consulted 10 February 2020).

Jenne, E. K., \& Mudde, C. 2012. “Hungary's Illiberal Turn: Can Outsiders Help?" Journal of democracy, 23(3): 147-155.

Landaburu, E. 2007. "The Need for Enlargement and Differences from Previous Accessions", in G. Vassiliou (ed.), The Accession Story: The EU from 15 to 25. (Oxford: Oxford University Press): 9-24.

Maniokas, K., 2004. "The method of EU Enlargement: A Critical Appraisal” in Dimitrova, A.L. (ed.) Driven to Change: The European Union's Enlargement Viewed from the East. (Manchester: Manchester University Press).

Maniokas, K. 2005. "Road to Negotiations: Enlargement Instruments and the Development of Lithuania's Status”, in K. Maniokas, R. Vilpišauskas \& D. Žeruolis (eds.) Lithuania's Road to the European Union: Unification of Europe and Lithuania's EU Accession Negotiation. (Vilnius: Eugrimas): 19-59.

Meyer-Sahling, J. 2004. "Civil service reform in post-communist Europe: the bumpy road to depoliticization", West European Politics 27(1): 71-103. 
Mirel, P. 2018. "The Western Balkans: Between stabilization and integration in the European Union", Foundation Robert Schuman Policy paper no 459, at: https:// www.robert-schuman.eu/en/doc/questions-d-europe/qe-459-en.pdf, (consulted 14 October 2019).

Mungiu-Pippidi, A. 2020. "The Rise and Fall of Good-Governance Promotion", Journal of Democracy, 31(1): 88-102.

Nikolova, K. 1998. 'The framework of the reform of the public management in Bulgaria: inside view' in Tony Verheijen and David Coombes. (eds.). Innovations in Public Management: Perspectives from East and West Europe. Cheltenham, Edward Elgar Publishers 59-102.

Parau, Cristina E. 2015. 'Explaining Governance of the Judiciary in Central and Eastern Europe: External Incentives, Transnational Elites and Parliamentary Inaction, Europe-Asia Studies, 67: 3, 409-442 DoI: 10.1080/09668136.2015.1016401

Preston, C. 1997. Enlargement and Integration in the European Union. (London and New York: Routledge).

Pridham, G. 2008. "The EU's Political Conditionality and Post Accession tendencies: Comparisons from Slovakia and Latvia", Jcms 46(2): 365-387.

Pridham, G. 2007. "Change and Continuity in the European Union's Political Conditionality: Aims, Approach, and Priorities", Democratization, 14(3): 446-471.

Primatarova, A. 2005. "The Closure of units 1-4 of the Kozloduy Nuclear Power Plant" in Engelbrekt, K. and Förberg, M. (eds.) Managing Political Crises in Bulgaria: Pragmatism and Procrastination. (Stockholm: Elanders Gotab): 97-138.

Racoviţă, M. 2011. 'Europeanization and Effective Democracy in Romania and Bulgaria', Romanian Journal of Political Sciences, 1, 28-49.

Sasse, G. 2008. "The politics of EU conditionality: the norm of minority protection during and beyond EU accession", Journal of European Public Policy 15(6): 842-86o.

Schimmelfennig, F. 2001. "The Community Trap: Liberal Norms, Rhetorical Action and the Eastern Enlargement of the European Union", International Organization 55(1): 47-80.

Schimmelfennig, F. and U. Sedelmeier (eds.), 2005. The Europeanization of Central and Eastern Europe. (Ithaca, NY: Cornell University Press).

Sedelmeier, U., and Lacatus, C. 2016. “Compliance with the European Union's AntiCorruption Conditions in the 'Cooperation and Verification Mechanism. Why is Romania Better than Bulgaria?" Maxcap Working Papers No 28 at: http://userpage .fu-berlin.de/kfgeu/maxcap/system/files/maxcap_wp_28.pdf (consulted 3 February 2020).

Smilov, D. 2006. "EU Enlargement and the Constitutional Principle of Judicial Independence", in W. Sadurski, A. Czarnota and M. Krygier (eds.), Spreading Democracy and the Rule of Law? Implications of EU Enlargement for the Rule of Law, Democracy and Constitutionalism in Post-Communist Legal Orders. (Netherlands: Springer). 
Smith, K. E. 1998. "The use of political conditionality in the EU's relations with third countries: How effective?" European foreign affairs review, 3(2): 253-274.

Steunenberg, B. and Dimitrova, A. 2007. "Compliance in the EU enlargement process: The limits of conditionality”, European Integration online Papers (EIoP), 11(5), available at: http://eiop.or.at/eiop/texte/2007-005a.htm (consulted 3 February 2020).

Strategy for the Establishment of a Modern Administrative System in the Republic of Bulgaria (1998) Council of Ministers, Republic of Bulgaria.

Szulecka, J., and K. Szulecki, 2013. "Analyzing the Rospuda River controversy in Poland: Rhetoric, environmental activism, and the influence of the European Union", East European Politics, 29(4): 397-419.

Toneva-Metodieva, L. 2014. "Beyond the Carrots and Sticks Paradigm: Rethinking the Cooperation and Verification Experience of Bulgaria and Romania", Perspectives on European Politics and Society 15(4): 1-18.

Tosheva, S. 1999. "Evropa hladno otblusna atakata na Kostov" [Europe met Kostov's attack with a cool rejection], Kapital [Capital newspaper)], g September 1999.

Trauner, F. 2009. "Post-Accession Compliance with EU Law in Bulgaria and Romania: A Comparative Perspective", European Integration online Papers (EIoP), Special Issue 2(13), 21, Available at: https://ssrn.com/abstract=1562666 (Consulted 3 February 2020).

Vassiliou, G. (ed.) 2007. The Accession Story: The EU from 15 to 25. (Oxford: Oxford University Press).

Velichkov, K. 2004. “Bulgaria's EU Accession negotiations: Achievements and Challenges”, Papeles del Este no 8, at: www.ucm.es/bucm/cee/papeles, (consulted ${ }_{15}$ October 2019).

Velinova, R., Bozhidarova, V. and V. Kolcheva 2001. "Politico-administrative relations in Bulgaria" in T. Verheijen, (ed.) Politico-Administrative Relations: Who Rules? (Bratislava: NispaCee): $64-85$.

Verheijen, T. 1999. "The civil service system of Bulgaria: Hope on the horizon" in Verheijen, T., and A. Kotchegura, (eds.) Civil service systems in Central and Eastern Europe. (Cheltenham: Edward Elgar).

Von Weizsäcker, R., J-L. Dehaene and D. Simon 1999. “The Institutional Implications of Enlargement”. (Brussels: Report to the European Commission).

Zankina, E. 2017. "Backdoor politics: Politicisation through restructuring in the Bulgarian civil service”, East European Politics 33(2): 291-308. 


\section{Appendix: List of Interviews}

\section{Interview 1}

Expert in the Bulgarian Ministry of Justice, 27 March 2006

Interview 2

Head of Unit in the Bulgarian Council of Ministers, 27 March 2006

Interview 3

Former Member of the Bulgarian negotiating team, 17 March 2016

Interview 4

Former Director in DG Enlargement European Commission

4a 31 October 2014

4 b 15 January 2015

4c 24 April 2015

Interview 516 April 2015

Former Director, DG Neighbourhood and Enlargement Negotiations, European Commission

Interview 616 April 2015

Commission official, DG Neighbourhood and Enlargement Negotiations, European Commission 